\title{
Desain Pedoman Implementasi Sistem Pengendalian Intern Pemerintah di Lingkungan Perguruan Tinggi Negeri
}

\author{
Imam Mulyono ${ }^{\mathrm{a}, *}$ dan Didik Purwantoro ${ }^{\mathrm{b}}$ \\ aPoliteknik Negeri Malang, imam.mulyono.polinema@gmail.com, Indonesia \\ ${ }^{\mathrm{b}}$ Politeknik Negeri Malang, Indonesia
}

\begin{abstract}
The Purpose of this research to evaluate and design guidelines implementation internal goverment control system in State Polytechnic of Malang. Kind of this research was descriptive using qualitative apporoach and the data that were used in this study were primer data colleted from interview result with internal audit unit at State Polytechnic of Malang. The result of this research indicate State Polytechnic of Malang don't have guidelines implementation internal goverment control system. Researcher recommended guidelines implementation internal goverment control system design at State Polytechnic of Malang for fulfill indicators: infrastructure needed to build, the implementation, and the legal basis. Advice for directure of State Polyechnic of Malang immediately communicate to all academic community so they can understand about guidelines implementation internal goverment control system.
\end{abstract}

Keywords: internal control, internal goverment control system, internal audit

\section{Pendahuluan}

Pemerintah Republik Indonesia memegang peran penting sebagai pembuat kebijakan dalam membentuk perundang-undangan di Negara Kesatuan Republik Indonesia dalam rangka mewujudkan sistem pemerintahan dengan tata kelola yang baik dan bersih. Peraturan Pemerintah Nomor 60 Tahun 2008 tentang Sistem Pengendalian Intern Pemerintah mewajibkan seluruh Instansi Pemerintah menerapkan Sistem Pengendalian Intern Pemerintah (SPIP) dalam seluruh rangkaian kegiatannya. Hal ini juga sudah disebutkan pada Peraturan Pemerintah Nomor 60 Tahun 2008 Pasal 2 Ayat 1 yaitu "untuk mencapai pengelolaan keuangan negara yang efektif, efisien, transparan, dan akuntabel, menteri/pimpinan lembaga, gubernur, dan bupati/walikota wajib melakukan pengendalian atas penyelenggaraan kegiatan pemerintah". Sistem Pengendalian Intern Pemerintah (SPIP) dikembangkan dengan mengadopsi konsepsi yang terbaik dan tepat sesuai dengan kondisi di Indonesia
Peraturan Pemerintah Nomor 60 Tahun 2008 tentang Sistem Pengendalian Intern Pemerintah merupakan salah satu instrumen penting dari UndangUndang Republik Indonesia Nomor 1 Tahun 2014 tentang Pembendaharaan Negara Pasal 55 ayat 4 bahwa Menteri/Pimpinan lembaga selaku Pengguna Anggaran/Pengguna Barang memberikan pernyataan bahwa pengelolaan APBN telah diselenggarakan berdasarkan sistem pengendalian intern yang memadai dan akuntansi keuangan telah diselenggarakan sesuai standar akuntansi pemerintah, Pasal 58 Ayat 2 yang menjelaskan bahwa dalam rangka meningkatkan kinerja, transparansi, dan akuntabilitas pengelolaan keuangan negara, Presiden selaku kepala pemerintahan mengatur dan menyelenggarakan sistem pengendalian intern di lingkungan pemerintahan secara menyeluruh. Pada tingkat Perguruan Tinggi BLU, dikeluarkanlah Peraturan Menteri Keuangan Republik Indonesia tentang Sistem Pengendalian Intern Pada Badan Layanan Umum pasal 2 ayat 1 yang menjelaskan

\footnotetext{
*Corresponding author. E-mail: imam.mulyono.polinema@gmail.com
} 
bahwa Pimpinan BLU menetapkan Sistem Pengendalian Intern Pada BLU.

Sistem Pengendalian Intern Pemerintah (SPIP) adalah proses yang integral pada tindakan dan kegiatan yang dilakukan secara terus menerus oleh pimpinan dan seluruh pegawai untuk memberikan keyakinan memadai atas tercapainya tujuan organisasi melalui kegiatan yang efektif dan efesien, keandalan pelaporan keuangan, pengamanan aset negara, dan ketaatan terhadap peraturan perundang-undangan. Sistem Pengendalian Intern Pemerintah (SPIP) bertujuan untuk memberikan keyakinan yang memadai guna tercapainya efektivitas dan efisiensi pencapaian tujuan penyelenggaraan pemerintah negara, keandalan pelaporan keuangan, pengamanan aset negara, dan ketaatan terhadap peraturan perundang-undangan (PP 60 Tahun 2008), Menurut Permenkeu tujuan Sistem Pengendalian Intern untuk tercapainya efektivitas dan efisiensi kegiatan BLU, keandalan dan integritas informasi keuangan dan kinerja BLU, pengamanan aset BLU, dan ketaatan terhadap peraturan perundang-undangan. The Comitte on Sponsoring the Treadway Committe (COSO) mendefinisakan juga arti dari sistem pengendalian intern yaitu proses yang dilakukan oleh manajemen dan personil lain dalam organisasi, yang dirancang untuk mendapatkan keyakinan yang memadai bahwa akan terdapat perbaikan dalam pencapaian tujuan: efektivitas dan efisiensi operasi, keandalan pelaporan keuangan, dan kepatuhan terhadap peraturan yang berlaku.

Sistem Pengendalian Intern Pemerintah (SPIP) dilaksanakan dengan lima unsur yaitu, lingkungan pengendalian, penilaian risiko, kegiatan pengendalian, informasi dan komunikasi, dan pemantauan pengendalian intern. Kelima unsur Sistem Pengendalian Intern Pemerintah (SPIP) menjadi fokus yang harus diperhatikan bagi instansi pemerintah dalam mencapai tujuan, baik tujuan umum instansi, tujuan unit, dan tujuan tingkat kegiatan. Penerapan unsur Sistem Pengendalian Intern Pemerintah (SPIP), pimpinan instansi pemerintah bertanggung jawab untuk mengembangkan kebijakan, prosedur dan praktik detail untuk menyesuaikan dengan kegiatan instansi pemerintah dan untuk memastikan bahwa unsur tersebut telah menyatu dan menjadi bagian integral dari kegiatan instansi pemerintah.

Peraturan Kepala BPKP tentang Pedoman Penyusunan Desain Penyelenggaraan Sistem Pengendalian Instansi Pemerintah (SPIP), pada pasal 2 ayat 1 menjelaskan bahwa, tujuan penyusunan desain penyelenggaraan SPIP adalah menginterprestasikan rencana pengembangan SPIP di lingkungan kementrian atau lembaga $(\mathrm{K} / \mathrm{L})$ dan pemerintah daerah (Pemda) sesuai dengan PP 60 tahun 2008, memberikan gambaran bagi K/L/Pemda tentang strategi penerapan SPIP, menjadi subtansi. Keputusan menteri atau kepala lembaga tentang penerapan SPIP di organisasinya, mendorong instansi pemerintah pusat dan daerah untuk melakukan percepatan penyelenggaraan SPIP, mengarahkan aktivitas pengembangan dan mengukur keberhasilan penyelenggaraan SPIP.

Penelitian tentang Sistem Pengendalian Intern Pemerintah (SPIP) pernah dilakukan oleh Ismani, dkk (2012) dengan judul "Implementasi Sistem Pengendalian Pemerintah di Universitas Negeri Yogyakarta". Hasil dari penelitian tersebut menyimpulkan bahwa implementasi unsur-unsur Sistem Pengendalian Intern Pemerintah di Universitas Negeri Yogyakarta sudah berjalan dengan baik dan sesuai dengan Peraturan Pemerintah Nomor 60 Tahun 2008. Ismani, dkk (2014) juga melakukan penelitian dengan topik yang sama dengan judul "Persepsi Pegawai Mengenai Implementasi Unsur-Unsur Sistem Pengendalian Intern Pemerintah untuk Menunjang Akuntabilitas Keuagan pada Universitas Negeri Yogyakarta". Tujuan dari penelitian tersebut untuk mengetahui presepsi pegawai terkait implementasi unsur-unsur Sistem Pengendalian Intern Pemerintah yang sudah diterapkan di Universitas Negeri Yogyakarta. Hasil yang diperoleh dari penelitian tersebut, untuk unsur lingkungan pengendalian memiliki presepsi dari pegawai tinggi, unsur penilaian risiko memiliki presepsi sangat tinggi, unsur kegiatan pengendalian memiliki presepsi tinggi, unsur informasi dan komunikasi memiliki presepsi sangat tinggi, unsur pemantauan pengendalian intern memiliki presepsi sangat tinggi. Penelitian terkait Sistem Pengendalian Intern Pemerintah (SPIP) juga pernah dilakukan oleh Zamzami dan Ihda (2014) dengan judul Evaluasi Implementasi Sistem Pengendalian Internal: Studi Kasus pada Sebuah Perguruan Tinggi Negeri. Hasil penelitian tersebut menunjukkan secara umum sistem pengendalian internal yang diterapkan oleh perguruan tinggi negeri telah dijalankan dengan baik dan sesuai dengan Sistem Pengendalian Intern Pemerintah yang diatur dalam peraturan pemerintah. Namun perlu pembenahan dalam aspek layanan pengadaan barang dan jasa, dokumentasi penilaian risiko, dan pengembangan aplikasi.

Dalam lingkup Instansi Pendidikan, penerapan Sistem Pengendalian Intern Pemerintah (SPIP) diharapkan juga dapat memberikan keyakinan yang memadai bagi tercapainya efektivitas dan efisiensi 
pencapaian tujuan penyelenggaan pemerintah negara, keandalan pelaporan keuangan, pengamanan aset negara, dan ketaatan terhadap peraturan perundangundangan. Politeknik Negeri Malang sebagai salah satu perguruan tinggi yang juga memiliki kewajiban untuk melaksanakan Peraturan Pemerintah Nomor 60 Tahun 2008.

Berdasarkan pemaparan di atas, peneliti memilih obyek pada Perguruan Tinggi Politeknik Negeri Malang. Alasan peneliti memilih Politeknik Negeri Malang adalah Politeknik Negeri Malang memberikan akses yang luas bagi peneliti untuk melakukan penelitian ini, disamping itu Politeknik Negeri Malang memerlukan rekomendasi terkait masalah Sistem Pengendalian Intern Pemerintah (SPIP) demi terlaksananya tata kelola instansi pemerinatah yang baik dan sesuai dengan peraturan pemerintah Nomor 60 Tahun 2008 tentang Sistem Pengendalian Intern Pemerintah.

Berdasarkan uraian latar belakang tersebut, peneliti tertarik melakukan penelitian dengan judul "Desain Pedoman Implementasi Sistem Pengendalian Intern Pemerintah di Lingkungan Perguruan Tinggi". Tujuan dari penelitian ini adalah untuk mengevaluasi dan mendesain pedoman implementasi sistem pengendalian intern pemerintah di Politeknik Negeri Malang.

\section{Kajian Pustaka}

Sistem pengendalian intern adalah pengendalian intern yang mencakup perencanaan organisasi dan seluruh metode organisasi dan ukuran yang diterapkan oleh suatu organisasi dalam rangka melindungi aset, memeriksa akurasi dan keandalan pencatatan yang dilakukan, meningkatkan efisiensi pelaksanaan kegiatan, serta mendorong dipatuhinya kebijakan pengelolaan kegiatan yang ditetapkan (BPKP, 2009). Dengan pengertian tersebut, secara umum sistem pengendalian intern diartikan sebagai rangkaian kegiatan, prosedur, proses, dan aspek lain yang berkaitan dengan pencapaian tujuan penciptaan pengendalian intern.

The Comitte on Sponsoring the Treadway Committe (COSO) mendefinisakan juga arti dari sistem pengendalian intern yaitu proses yang dilakukan oleh manajemen dan personil lain dalam organisasi, yang dirancang untuk mendapatkan keyakinan yang memadai bahwa akan terdapat perbaikan dalam pencapaian tujuan: efektivitas dan efisiensi operasi, keandalan pelaporan keuangan, dan kepatuhan terhadap peraturan yang berlaku. Dengan adanya konsep dari COSO ini, ciri yang paling berpengaruh pada efektivitas pengendalian adalah proses, hal ini membawa konsekuensi bahwa kesadaran akan pentingnya pengendalian tidak boleh hanya menjadi tanggung jawab top manajemen namun tersebar kepada seluruh anggota organisasi, tidak hanya sampai kepada unit dan bagian organisasi yang terkecil, tetapi sampai ke individu. Menurut COSO komponen sistem pengendalian intern terdapat 5 unsur yaitu lingkungan pengendalian, penilaian risiko, aktivitas pengendalian, informasi dan komunikasi, dan pemantauan.

Keberhasilan Sistem Pengendalian Intern Pemerintah (SPIP) sangat bertumpu tidak hanya pada rancangan pengendalian yang memadai untuk menjamin tercapainya tujuan organisasi, tetapi juga kepada setiap orang dalam organisasi, sebagai faktor yang dapat membuat pengendalian tersebut berfungsi. Sejalan dengan pemahaman bahwa pengendalian dirancang sesuai kebutuhan organisasi, Peraturan Pemerintah Nomor 60 Tahun 2008 tentang Sistem Pengendalian Intern Pemerintah (SPIP) juga menyebutkan bahwa sistem pengendalian intern dalam penerapannya harus memperhatikan rasa keadilan dan kepatuhan serta mempertimbangkan ukuran, kompleksitas, dan sifat dari tugas dan fungsi Instansi Pemerintah tersebut. Berdasarkan Peraturan Pemerintah Nomer 60 Tahun 2008 tersebut, Sistem Pengendalian Intern Pemerintah (SPIP) terdiri dari 5 unsur, yaitu lingkungan pengendalian. Lingkungan Pengendalian adalah kondisi dalam instansi pemerintah yang dapat membangun kesadaran semua personil akan pentingnya pengendalian dalam organisasi dalam menjalankan aktivitas yang menjadi tanggung jawabnya sehingga meningkatnya efektivitas pengendalian intern.

\section{Lingkungan Pengendalian}

Peraturan Pemerintah Nomor 60 Tahun 2008 Pasal 4 menjelaskan bahwa, pimpinan instansi pemerintah wajib menciptakan dan memelihara lingkungan pengendalian yang menimbulkan perilaku positif dan kondusif untuk penerapan Sistem Pengendalian Intern dalam lingkungan kerjanya, melalui:

a. Penegakan integritas dan nilai etika

b. Komitmen terhadap kompetensi

c. Kepemimpinan yang kondusif

d. Pembentukan struktur organisasi

e. Pendelegasian wewenang dan tanggung jawab

f. Penyusunan dan penerapan kebijakan 


\author{
g. Hubungan kerja yang baik dengan instansi \\ pemerintah \\ h. Penilaian risiko
}

Penilaian risiko adalah kegiatan penilaian atas kemungkinan kejadian yang mengancam pencapaian tujuan dan sasaran instansi pemerintah yang meliputi kegiatan identifikasi, analisis, dan mengelola risiko yang relevan bagi proses atau kegiatan organisasi. Peraturan Pemerintah Nomor 60 Tahun 2008, Pasal 13 ayat menyatakan bahwa pimpinan instansi pemerintah wajib melakukan penilaian risiko. Penilaian risiko terdiri dari dua tahapan penting, yaitu identifikasi risiko dan analisis risiko. Sebelum kedua tahapan tersebut dilaksanakan, pimpinan instansi pemerintah terlebih dahulu harus merumuskan tujuan, baik itu tujuan instansi maupun tujun tingkat kegiatan. Perumusan tujuan ini mutlak dilakukan karena penilaian risiko didasarkan atas kemungkinan kejadian yang menghambat pencapaian tujuan yang telah ditetapkan.

Peraturan Pemerintah Nomor 60 Tahun 2008 Pasal 14 secara spesifik memberi arahan bagaimana seharusnya pimpinan instansi pemerintah menetapkan tujuan. Tujuan instansi pemerintah harus memuat pernyataan dan arahan yang spesifik, terukur, dapat dicapai, realistis dan terikat waktu. Setelah tujuan ditetapkan, tujuan tersebut wajib dikomunikasikan kepada seluruh pegawai. Dalam rangka mencapai tujuan yang telah ditetapkan, pimpinan instansi pemerintah kemudian menyusun strategi, yaitu strategi operasional yang konsisten dan strategi manajemen terintegrasi dan rencana penilaian risiko. Langkah terakhir dari penilaian risiko adalah analisis risiko. Pasal 17 dalam Peraturan Pemerintah Nomor 60 Tahun 2008 mengatur bahwa analisis risiko dilaksanakan untuk menentukan status dari risiko yang telah diidentifikasi terhadap pencapaian tujuan instansi pemerintah.

\section{Kegiatan Pengendalian}

Kegiatan Pengendalian adalah tindakan yang diperlukan untuk mengatasi risiko serta penetapan dan pelaksanaan kebijakan dan prosedur untuk memastikan bahwa tindakan mengatasi risiko telah dilaksanakan secara efektif. Kegiatan pengendalian terdiri dari:

a. Reviu kinerja

b. Pembinaan sumber daya manusia

c. Pengendalian atas pengelolaan sistem informasi

d. Pengendalian fisik atas aset e. Penetapan reviu atas indikator dan ukuran kinerja

f. Pemisahan fungsi

g. Otorisasi atas transaksi dan kejadian yang penting

h. Pencatatan yang akurat dan tepat waktu atas transaksi dan kejadian

i. Pembatasan akses atas sumber daya dan pencatatannya

j. Akuntabilitas terhadap sumber daya dan pencatatannya

k. Dokumentasi yang baik atas sistem pengendalian intern serta transaksi dan kejadian penting

1. Informasi dan komunikasi

Informasi adalah data yang telah diolah yang dapat digunakan untuk pengambilan keputusan dalam rangka penyelenggaraan tugas dan fungsi instansi pemerintah. Komunikasi adalah proses penyampaian pesan atau informasi dengan menggunakan simbol atau lambang tertentu baik secara langsung maupun tidak langsung untuk mendapatkan umpan balik. Peraturan Pemerintah Nomor 60 Tahun 2008 Pasal 41 menjelaskan bahwa, pimpinan instansi pemerintah wajib mengidentifikasi, mencatat dan mengkomunikasikan informasi dalam bentuk dan waktu yang tepat secara efektif. Untuk menyelenggarakan komunikasi yang efektif, pimpinan instansi pemerintah harus:

a. Menyediakan dan memanfaatkan berbagai bentuk dan sarana komunikasi

b. Mengelola, mengembangkan, dan memperbaharui sistem informasi secara terus menerus

\section{Pemantauan}

Pemantauan adalah proses penilaian atas mutu kinerja sistem pengendalian intern dan proses yang memberikan keyakinan bahwa temuan audit dan evaluasi lainnya segera ditindaklanjuti. Peraturan Pemerintah Nomor 60 Tahun 2008 Pasal 43 menjelaskan bahwa, pimpinan pemerintah wajib melakukan pemantauan sistem pengendalian intern yang dilaksanakan melalui pemantauan berkelanjutan, evaluasi terpisah, dan tindak lanjut rekomendasi hasil audit dan reviu lainnya.

Pemantauan berkelanjutan diselenggarakan melalui kegiatan rutin, supervisi, pembandingan, rekonsiliasi, dan tindakan lain yang terkait dalam pelaksanaan tugas. Evaluasi terpisah diselenggarakan melalui penilaian sendiri, reviu, dan pengujian efektifitas 
sistem pengendalian intern. Evaluasi terpisah dapat dilakukan oleh aparat pengawasan intern pemerintah atau pihak eksternal pemerintah. Tindak lanjut rekomendasi audit dan reviu lainnya harus segera diselesaikan dan dilaksanakan sesuai dengan mekanisme penyelesaian rekomendasi hasil audit dan reviu lainnya yang ditetapkan.

\section{Metode Penelitian}

Lokasi penelitian ini dilakukan di perguruan tinggi Politeknik Negeri Malang yang beralamat di Jl. Soekarno-Hatta No. 9 Malang, merupakan salah satu perguruan tinggi negeri yang memiliki kewajiban menerapkan Sistem Pengendalian Intern Pemerintah (SPIP) dengan mengacu pada Peraturan Pemerintah Nomor 60 Tahun 2008 tentang Sistem Pengendalian Intern Pemerintah. Jenis penelitian adalah deskriptif dengan pendekatan kualitatif. Sumber data yang digunakan adalah data primer yaitu hasil wawancara dengan pejabat Satuan Pengawasan Internal terkait sistem pengendalian intern pemerintah di Politeknik Negeri Malang. Teknik analisis data dengan tahapan:

1. Mengidentifikasi Sistem Pengendalian Intern Pemerintah (SPIP) di Politeknik Negeri Malang.

2. Mengidentifikasi undang-undang, peraturan pemerintah, peraturan menteri keuangan yang berhubungan dengan Sistem Pengendalian Intern Pemerintah.

3. Mengidentifikasi bentuk implementasi Sistem Pengendalian Intern Pemerintah (SPIP) di Politeknik Negeri Malang.

4. Menyusun pertanyaan atas wawancara yang berkaitan dengan Sistem Pengendalian Intern Pemerintah (SPIP)

5. Melakukan FGD dengan pejabat SPI

6. Menyusun pedoman implementasi Sistem Pengendalian Intern Pemerintah (SPIP)

\section{Hasil dan Pembahasan}

Politeknik Negeri Malang merupakan salah satu perguruan tinggi negeri yang memiliki kewajiban untuk melaksanakan pengendalian atas penyelenggaraan kegiatan pemerintah sesuai dengan intruksi Peraturan Pemerintah Nomor 60 Tahun 2008. Dalam rangka memenuhi kewajibannya, Politeknik Negeri Malang menerapkan Sistem Pengendalian Intern Pemerintah (SPIP) dengan mengacu kepada Peraturan Pemerintah Nomor 60 Tahun 2008. Sistem
Pengendalian Intern Pemerintah (SPIP) berfungsi untuk memberikan arah yang jelas atas tercapainya tujuan organisasi dengan membangun lima unsur yaitu lingkungan pengendalian, penilaian risiko, kegiatan pengendalian, informasi dan komnikasi, dan pemantauan pengendalian intern. Peraturan Pemerintah Nomor 60 Tahun 2008 tentang Sistem Pengendalian Intern Pemerintah (SPIP) merupakan instrumen dari Undang-Undang Republik Indonesia Nomor 1 Tahun 2004 yang menjelaskan bahwa dalam rangka meningkatkan kinerja, transparansi, dan akuntabilitas pengelolaan keuangan negara, Presiden selaku kepala pemerintahan mengatur dan menyelenggarakan sistem pengendalian intern di lingkungan pemerintahan secara menyeluruh.

Berdasarkan focus group discussion dengan Pejabat Satuan Pengawasan Intern (SPI) Politeknik Negeri Malang terkait Sistem Pengendalian Intern Pemerintah (SPIP), Politeknik Negeri Malang belum mempunyai dokumen pedoman implementasi Sistem Pengendalian Intern Pemerintah (SPIP). Untuk menerapkan sub unsur Sistem Pengendalian Intern Pemerintah (SPIP) diperlukan panduan dalam mengimplementasikan unsur-unsur Sistem Pengendalian Intern Pemerintah (SPIP) guna mendukung kelancaran pelaksanaan implementasi. Berikut adalah pembahasan hasil penelitian yaitu berupa dokumen pedoman implementasi sistem pengendalian intern pemerintah di Politeknik Negeri Malang.

\section{Lingkungan Pengendalian}

a. Penegakan integritas dan nilai etika

Infrastruktur yang perlu dibangun oleh pimpinan Politeknik Negeri Malang untuk sub unsur penegakan integritas dan nilai etika adalah menyusun dokumen kode etik dan aturan perilaku untuk seluruh pegawai Politeknik Negeri malang serta menegakkan aturan perilaku yang telah disusun dengan cara memberi keteladanan yang baik kepada seluruh pegawai dalam mematuhi peraturan.

b. Komitmen terhadap kompetensi

Infrastruktur yang perlu dibangun oleh pimpinan Politeknik Negeri Malang untuk sub unsur komitmen terhadap kompetensi adalah menetapkan visi, misi dan tujuan yang ingin dicapai dalam bentuk RBA atau renstra Politeknik Negeri Malang melalui identifikasi dan penetapan kegiatan yang dibutuhkan untuk menyelesaikan tugas dan fungsi dalam pencapaian kinerja dan mengkomunikasikan kepada seluruh pegawai Politeknik Negeri Malang.

c. Kepemimpinan yang kondusif 
Pimpinan Politeknik Negeri Malang perlu membangun Infrastruktur sistem pengendalian intern pemerintah untuk sub unsur kepemimpinan yang kondusif adalah mengeluarkan kebijakan-kebijakan terkait manajemen risiko, manajemen berbasis kinerja, perlindungan aset dan informasi, dan fungsi-fungsi penting di Politeknik Negeri Malang. Penerapan kepemimpinan yang kondusif dapat dilakukan dengan cara upaya untuk selalu mempertimbangkan risiko yang dapat menghambat pencapaian risiko, penerapan manajemen berbasis kinerja, mendukungk fungsifungsi penting di Politeknik Negeri Malang, melindungi aset dan informasi dari pengguna yang tidak sah, dan merespon positif terhadap pelaporan.

d. Pembentukan struktur organisasi yang sesuai dengan kebutuhan

Infrastruktur yang perlu dibangun oleh pimpinan Politeknik Negeri Malang untuk sub unsur pembentukan struktur organisasi adalah menetapkan struktur organisasi sesuai dengan kebutuhan, kejelasan wewenang dan tanggung jawab kemudian melaksanakan evaluasi dan penyesuain dengan rencana strategis Politeknik Negeri Malang. Penerapan pembentukan struktur organisasi dengan mengkomunikasikan struktur organisasi kepada seluruh pegawai Politeknik Negeri Malang dan memahami tugas dan tanggung jawabnya

e. Pendelegasian wewenang dan tanggung jawab yang tepat

Infrastruktur yang perlu dibangun oleh pimpinan Politeknik Negeri Malang untuk sub unsur pendelegasian wewenang dan tanggung jawab yang tepat adalah menyusun dokumen pendelegasian wewenang dan tanggung jawab dengan cara wewenang dan tanggung jawab yang telah ditetapkan dan dikomunikasikan kepada seluruh pegawai yang terkait, kemudian penerima wewenang dan tanggung jawab memberi umpan balik atas pendelegasian tugas yang diberikan

f. Penyusunan dan penerapan kebijakan yang sehat tentang pembinaan sumber daya manusia

Infrastruktur yang perlu dibangun oleh pimpinan Politeknik Negeri Malang untuk sub unsur penyusunan dan penerapan kebijakan yang sehat tentang pembinaan sumber daya manusia adalah menetapkan kebijakan dan prosedur mulai rekruitmen sampai dengan pemberhentian pegawai dengan cara pimpinan Politeknik Negeri Malang memberikan arahan, mengkomunikasikan kebijakan, tujuan, serta target yang ingin dicapai kepada pegawai yang bersangkutan.

g. Perwujudan peran aparat pengawasan intern pemerintah yang efektif
Infrastruktur yang perlu dibangun oleh pimpinan Politeknik Negeri Malang untuk sub unsur perwujudan peran aparat pengawasan intern pemerintah yang efektif adalah kebijakan terkait penetapan kedudukan APIP yang independen dan fungsi konsultasi. Penerapan yang perlu dilakukan oleh pimpinan Politeknik Negeri Malang adalah Pimpinan Politeknik Negeri Malang terhadap yang diperiksa harus independen dan profesional dalam menganggapi rekomendasi dari APIP.

h. Hubungan kerja yang baik dengan instansi pemerintah terkait.

Pimpinan Politeknik Negeri Malang perlu membangun infrastruktur sistem pengendalian intern pemerintah untuk sub unsur hubungan kerja yang baik dengan instansi pemerintah adalah kebijakan terkait dengan kegiatan-kegiatan yang perlu dikoordinasikan yang berhubungan dengan pengelolaan keuangan, pengendalian intern, dan peningkatan kinerja. Penerapan dari sub unsur hubungan kerja yang baik dengan instansi pemerintah dengan membentuk wadah yang akan menjadi pelaksana koordinasi dengan piak instansi pemerintah lainnya kemudian menginformasikan dan mendorong seluruh pegawai Politeknik Negeri Malang mengenai perlunya koordinasi dengan instansi pemerintah lainnya.

\section{Penilaian risiko}

\section{a. Identifikasi risiko}

Langkah awal yang perlu dilakukan oleh pimpinan Politeknik Negeri Malang dalam menilai risiko adalah mengidentifikasi risiko dalam bentuk daftar risiko untuk menetapkan dan mengkategorikan risiko yang mempengaruhi pencapaian tujuan kemudian dikomunikasikan kepada seluruh pegawai Politeknik Negeri Malang untuk segera ditindaklanjuti.

b. Analisis risiko

Setelah melakukan identifikasi risiko, langkah selanjutnya yang perlu diambil oleh pimpinan Politeknik Negeri Malang yaitu menganalisis risiko dengan output daftar urutan prioritas risiko dan daftar risiko yang akan ditangani kemudian dikomunikasikan kepada seluruh pegawai yang berwenang terkait hasil analisis risiko.

\section{Kegiatan pengendalian}

a. Reviu kinerja

Infrastruktur yang perlu dibangun oleh pimpinan Politeknik Negeri Malang untuk sub unsur reviu kinerja adalah membangun sistem pengukuran kinerja yang terukur dan membangun akuntabilitas kinerja melalui pelaporan dengan cara pimpinan dan pejabat 
pengelola keuangan Politeknik Negeri Malang melakukan reviu terhadap kegiatan yang berkaitan dengan aktivitas pengendalian.

b. Pembinaan sumber daya manusia

Infrastruktur yang perlu dibangun oleh pimpinan Politeknik Negeri Malang untuk sub unsur pembinaan sumber daya manusia adalah melalui kebijakan dan prosedur untuk memastikan efektifitas tindakan dalam mengatasi risiko dengan cara mendorong pimpinan dan pegawai untuk menyadari tugas dan tanggung jawab dan pimpinan harus bertindak sebagai panutan kemudian dikomunikasikan kepada seluruh pegawai.

c. Pengendalian atas pengelolaan sistem informasi

Infrastruktur yang perlu dibangun oleh pimpinan Politeknik Negeri Malang untuk sub unsur pengendalian atas pengelolaan sistem informasi adalah menetapkan kebijakan-kebijakan yang berkaitan dengan pengendalian atas pengelolaan sistem informasi kemudian dikomunikasikan kepada seluruh pegawai Politeknik Negeri Malang.

d. Pengendalian fisik atas aset

Infrastruktur yang perlu dibangun oleh pimpinan Politeknik Negeri Malang untuk sub unsur pengendalian fisik atas aset adalah rencana identifikasi, kebijakan, dan prosedur pengamanan fisik atas aset dengan cara mendorong pimpinan dan seluruh pegawai Politeknik Negeri Malang untuk memahami dan menerapkan pengendalian fisik atas aset, menyadari tugas dan tanggung jawabnya.

e. Penetapan reviu atas indikator dan ukuran kinerja

Infrastruktur yang perlu dibangun oleh pimpinan Politeknik Negeri Malang untuk sub unsur penetapan reviu atas indikator dan ukuran kinerja adalah menetapkan Indikator dan Ukuran Kinerja melalui penyusunan SOP penetapan indikator dan ukuran kinerja.

\section{f. Pemisahan fungsi}

Infrastruktur yang perlu dibangun oleh pimpinan Politeknik Negeri Malang untuk sub unsur pemisah fungsi adalah kebijakan pimpinan Politeknik Negeri Malang dan prosedur secara tertulis atas pemisah fungsi tersebut. Penerapan dari sub unsur pemisah fungsi ini melalui terlaksananya pemisah fungsi dari tingkat instansi sampai tingkat kegiatan instansi, selanjutnya diformalkan dalam bentuk surat keputusan direktur kemudian dikomunikasikan kepada pegawai yang bersangkutan.

g. Otorisasi atas transaksi dan kejadian yang penting

Infrastruktur yang perlu dibangun oleh pimpinan Politeknik Negeri Malang untuk sub unsur otorisasi atas transaksi dan kejadian yang penting adalah menetapkan kebijakan dan SOP dengan mempertimbangkan tujuan pengendalian dan risiko. Internalisasi yang perlu dilakukan oleh pimpinan Politeknik Negeri Malang dengan cara mengkomunikasikan secara rutin kepada seluruh pegawai Politeknik Negeri Malang pentingnya otorisasi atas transaksi dan kejadian yang penting.

h. Pencatatan yang akurat dan tepat waktu atas transaksi dan kejadian

Infrastruktur yang perlu dibangun oleh pimpinan Politeknik Negeri Malang untuk sub unsur pencatatan yang akurat dan tepat waktu atas transaksi dan kejadian adalah menetapkan kebijakan dan SOP terkait kegiatan pencatatan dengan cara memperhatikan kesadaran atas risiko tidak dilaksanakannya pencatatan yang akurat dan tepat waktu atas transaksi dan kejadian melalui kegiatan sosialisasi terhadap kebijakan dan prosedur yang telah disusun

i. Pembatasan akses atas sumber daya dan pencatatannya

Infrastruktur yang perlu dibangun oleh pimpinan Politeknik Negeri Malang untuk sub unsur pembatasan akses atas sumber daya dan pencatatannya adalah menetapkan kebijakan dan SOP terkait pembatasan akses selanjutnya dikomunikasikan kepada seluruh pegawai terkait kebijakan tersebut dan kepada seluruh pihak sesuai dengan kewenangannya

j. Akuntabilitas terhadap sumber daya dan pencatatannya

Infrastruktur yang perlu dibangun oleh pimpinan Politeknik Negeri Malang untuk sub unsur akuntabilitas terhadap sumber daya dan pencatatannya adalah menetapkan kebijakan dan SOP terkait akuntabilitas terhadap sumber daya dan pencatatannya, kemudian kebijakan dan SOP tersebut di laksanakan oleh seluruh pihak yang berkaitan

k. Dokumentasi yang baik atas sistem pengendalian intern serta transaksi dan kejadian penting

Infrastruktur yang perlu dibangun oleh pimpinan Politeknik Negeri Malang untuk sub unsur dokumentasi atas sistem pengendalian intern serta transaksi dan kejadian penting adalah kebijakan pimpinan di tingkat instansi dan kegiatan dengan internalisasi dikomunikasikan kepada seluruh pegawai Politeknik Negeri Malang dan pengembangan dokumentasi baik di tingkat instansi maupun kegiatan.

4. Informasi dan Komunikasi

a. Informasi 
Pimpinan Politeknik Negeri Malang perlu membangun infrastruktur sistem pengendalian intern pemerintah untuk sub unsur informasi adalah investigasi sistem informasi, analisis sistem informasi, rancangan sistem informasi, pengembangan sistem informasi. Internalisasi yang dapat dilakukan oleh pimpinan Politeknik Negeri Malang adalah menguji sistem informasi dan melakukan pelatihan sistem terkait.

b. Komunikasi

Infrastruktur yang perlu dibangun oleh pimpinan Politeknik Negeri Malang untuk sub unsur komunikasi adalah menyusun kebijakan dan prosedur terkait komunikasi internal, sarana dan prasana komunikasi. Internalisasi yang perlu dilakukan pimpinan adalah pimpinan Politeknik Negeri Malang rutin berinteraksi dengan selaruh pegawai dan pegawai antar pegawai terkait tugas, wewenang dan tanggung jawabnya.

\section{Pemantauan Pengendalian Internal}

a. Pemantauan Berkelanjutan

Infrastruktur yang perlu dibangun oleh pimpinan Politeknik Negeri Malang untuk sub unsur pemantauan berkelanjutan adalah pelaksanaan pemantauan berkelanjutan. Internalisasi untuk pelaksanaan pemantauan berkelanjutan melaui strategi pimpinan dalam melakukan pemantauan sistem pengendalian intern yang ada pada lingkup kerjanya.

b. Evaluasi terpisah

Infrastruktur yang perlu dibangun oleh pimpinan Politeknik Negeri Malang untuk sub unsur evaluasi terpisah adalah kebijakan atas tindak lanjut hasil temuan audit melalui sikap tanggap pimpinan merespon tindak lanjut atas temuan audit.

\section{Kesimpulan}

Berdasarkan hasil penelitian dan pembahasan tentang Sistem Pengendalian Intern Pemerintah yang dilakukan di Politeknik Negeri Malang, dapat diambil kesimpulan bahwa Sistem Pengendalian Intern Pemerintah merupakan salah satu cara sebuah instansi pemerintah dalam mencapai pengelolaan keuangan negara yang efektif, efisien, transparan, dan akuntabel. Implementasi Sistem Pengendalian Intern Pemerintah di Politeknik Negeri Malang belum optimal dikarenakan belum adanya pedoman implementasi sistem pengendalian intern pemerintah.
Pedoman implementasi sistem pengendalian intern pemerintah disusun dengan metode wawancara dan FGD dengan pejabat SPI Politeknik Negeri Malang sehingga menghasilkan pedoman implementasi sistem pengendalian intern pemerintah yang berisi:

a. Infrastruktur yang perlu di bangun oleh Politeknik Negeri Malang

b. Internalisasi atau penerapannya, dan

c. Dasar hukum yang melandasi pedoman tersebut

Berdasarkan kesimpulan di atas, penulis merekomendasikan saran dan masukan yang sekiranya bermanfaat bagi kemajuan dan perkembangan Politeknik Negeri Malang dari segi ketaatan terhadap peraturan sehingga dapat menjadikan Politeknik Negeri Malang sebagai instansi pemerintah yang baik dan taat terhadap peraturan yang berlaku. Berikut ini adalah saran-saran dari penulis:

\section{Bagi Politeknik Negeri Malang}

Sebaiknya Pimpinan Politeknik Negeri Malang mengimplementasikan dan memantau Sistem Pengendalian Intern Pemerintah sesuai dengan Peraturan Pemerintah Nomor 60 Tahun 2008 dengan optimal untuk mencapai keuangan negara yang efektif, efisien, transparan, dan akuntabel. Selanjutnya pimpinan Politeknik Negeri Malang mendokumentasikan pedoman implementasi atau penerapan Sistem Pengendalian Intern Pemeritah supaya seluruh pegawai yang bersangkutan mengerti dalam pelaksanaan fungsi pengendalian intern di Politeknik Negeri Malang.

2. Bagi peneliti selanjutnya

Saran untuk peneliti selanjutnya, objek penelitian dilakukan di pemerintah daerah yang masih belum menerapkan sistem pengendalian intern pemerintah. Alasannya karena pemerintah daerah sebagai salah satu instansi pemerintah yang wajib menerapkan Sistem Pengendalian Intern Pemerintah.

\section{References}

Ismani, dkk. (2012). Presepsi Pegawai Mengenai Implementasi Unsur-Unsur Sistem Pegendalian Intern Pemerintah untuk Menunjang Akuntabilitas Keuangan pada Universitas Negeri Yogyakarta, Yogyakarta.

Zamzami F \& Faiz IA. (2015). Evaluasi Implementasi Sistem Pengendalian Internal: Studi Kasus pada Sebuah Perguruan Tinggi Negeri. Jurnal Akuntansi Multiparadigma, 6 (1), 20-27. 
Ismani dkk. (2014). Implementasi Sistem Pengendalian Intern Pemerintah di Universitas Negeri Yogyakarta. Jurnal Economia, 10 (1), 24-37.

Undang-Undang Republik Indonesia Nomor 1 Tahun 2004 tentang Perbendaharaan Negara.

Peraturan Pemerintah Republik Indonesia Nomer 60 Tahun 2008 tentang Sistem Pengendalian Intern Pemerintah.

Peraturan Menteri Keuangan Republik Indonesia Nomor 200/PMK.05/2017 tentang Sistem Pengendalian Intern Pada Badan Layanan Umum.

Peraturan Kepala Badan Pengawasan Keuangan dan Pembangunan Nomor: PER-687/K/D4/2012 tentang Pedoman Penyusunan Desain Penyelenggaraan Sistem Pengendalian Intern Pemerintah.

Intruksi Presiden Republik Indonesia Nomor 4 Tahun 2011 tentang Percepatan Peningkatan Kualitas Akuntabilitas Negara.

Sugiyono. (2016). Metode Penelitian Manajemen. Bandung: Alfabeta.

Indriantoro, Nur. \& Bambang Supomo. (2009). Metodologi Penelitian Bisnis. Yogyakarta: BPFE-Yogyakarta.

Sujarweni, V. Wiratna. (2014). Metodologi Penelitian. Yogyakarta: Pustaka Baru Press. 